Full length article

\title{
Triassic vegetation and climate evolution on the northern margin of Gondwana: a palynological study from Tulong, southern Xizang (Tibet), China
}

\author{
Jungang Peng ${ }^{\mathrm{a}}$, Jianguo Li ${ }^{\mathrm{b}, *}$, Sam M. Slater ${ }^{\mathrm{c}}$, Qianqi Zhang ${ }^{\mathrm{a}, \mathrm{d}}$, Huaicheng Zhu ${ }^{\mathrm{b}}$, Vivi Vajda ${ }^{\mathrm{c}}$ \\ ${ }^{\text {a } C A S ~ K e y ~ L a b o r a t o r y ~ o f ~ E c o n o m i c ~ S t r a t i g r a p h y ~ a n d ~ P a l a e o g e o g r a p h y, ~ N a n j i n g ~ I n s t i t u t e ~ o f ~ G e o l o g y ~ a n d ~ P a l a e o n t o l o g y ~ a n d ~ C e n t e r ~ f o r ~ E x c e l l e n c e ~ i n ~ L i f e ~ a n d ~}$ \\ Paleoenvironment, Chinese Academy of Sciences, Nanjing 210008, China \\ ${ }^{\mathrm{b}}$ State Key Laboratory of Palaeobiology and Stratigraphy, Nanjing Institute of Geology and Palaeontology and Center for Excellence in Life and Paleoenvironment, Chinese \\ Academy of Sciences, Nanjing 210008, China \\ ${ }^{c}$ Department of Palaeobiology, Swedish Museum of Natural History, Stockholm 104 05, Sweden \\ d University of Chinese Academy of Sciences, Beijing 100049, China
}

\section{A R T I C L E I N F O}

\section{Keywords:}

Palaeovegetation

Palaeoclimate

Palynology

Tectonics

Triassic

Tethys Ocean

\begin{abstract}
A B S T R A C T
We present vegetation reconstructions based on an almost complete succession through the Triassic of Tulong, Nyalam County, southern Xizang (Tibet), China. The Permian and earliest Triassic samples were barren of palynomorphs, however, in overlying strata we identified well-preserved and diverse miospore assemblages. Seven pollen and spore zones spanning the Olenekian to the Rhaetian were recognized. These palynological zones were amalgamated into three floral stages that comprise distinct vegetation types: (1) an early Olenekian lycophytedominated flora with common pteridosperms, indicative of a warm and dry climate; (2) a late Olenekian transitional flora composed of abundant conifers with low abundances of lycophytes, signifying a decrease in temperature and increase in humidity; (3) a Middle to Late Triassic mature conifer-dominated flora with diverse sphenophytes, ferns and cycadophytes, indicative of a stable, temperate and humid climate. The changes in vegetation and climate tentatively correlate with the rifting of northern Gondwana, suggesting that regional tectonics was a contributive driving factor to local floral community change.
\end{abstract}

\section{Introduction}

Detailed palaeobotanical and palynological data from the Triassic of China are relatively limited compared to European and North American records (Kustatscher et al., 2018). Traditionally, four major basins have been the focus of Chinese Triassic palaeobotany, all with well-exposed continental Triassic successions yielding diverse macro- and microfloras. These basins are the Junggar and Tarim basins in the northwestern part of the country (Deng et al., 2010; Sha et al., 2011, 2015; Peng et al., 2018a), the Ordos Basin in North China (Qu, 1980; Huang and Zhou, 1980) and the Sichuan Basin in South China (Wang et al., 2010; Li et al., 2016a, 2016b, 2017).

Southern Xizang (Tibet), located in the southwestern part of China, hosts continuous and extensive successions of well-exposed near-shore marine Triassic sedimentary deposits that include, among other fossil groups, rich pollen and spore assemblages (Rao et al., 1987; SchneebeliHermann et al., 2012; Peng et al., 2018b). This area was situated on the northern margin of Gondwana during the Triassic (Ogg and von Rad,
1994), and represents an important region to further understand the development of terrestrial ecosystems and vegetation of northern Gondwana during a key developmental phase of the evolution of the Tethys Ocean (e.g., Pan et al., 2012).

Here we present a stratigraphical framework for the Triassic based on terrestrial palynomorphs from southern Xizang which allows us to explore climatic variations through a succession comprising most of the Triassic, and compare these findings with the global record and regional tectonic evolution.

\section{Geological setting}

During the Late Permian and the Triassic, Tulong was located at $\sim 30^{\circ} \mathrm{S}$ on the northern margin of Gondwana in the Southern Hemisphere (Ogg and von Rad, 1994). This area is part of the Himalayan Tethys Block (southern Xizang) that lies between the Indian shield to the south and the Yarlung Zangbo suture to the north (Yin and Harrison, 2000; Zhang et al., 2013). The palynological samples of this

\footnotetext{
* Corresponding author.

E-mail address: jgli@nigpas.ac.cn (J. Li).
} 


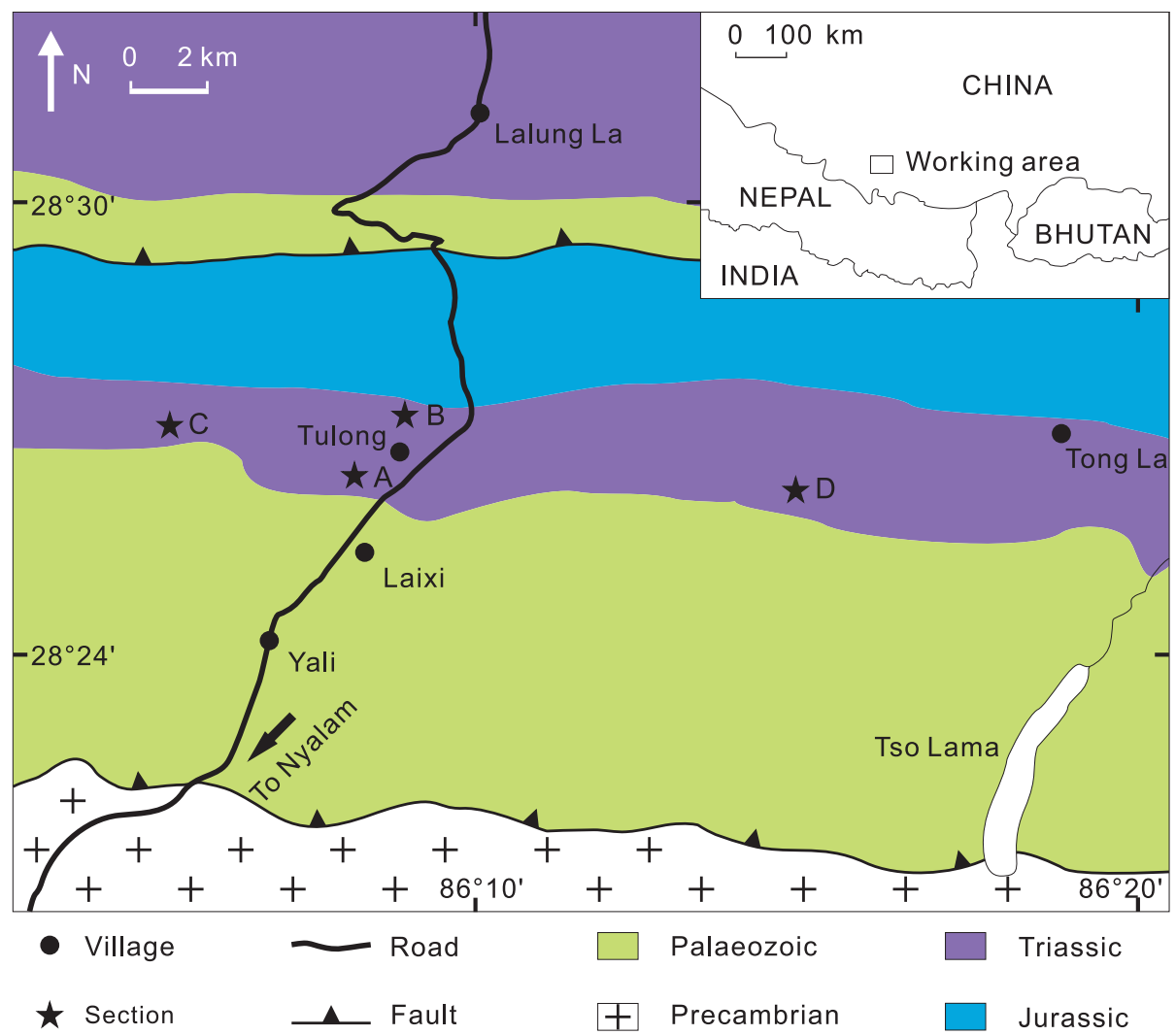

Fig. 1. Geological map of the study area (after Brühwiler et al., 2009) and locations of studied sections. Studied sections are marked by stars.

study were collected from four outcrop sections (A, B, C and D), located near Tulong village in the north of Nyalam County, southern Xizang (Figs. 1 and 2). According to Wang et al. (1980), the marine Triassic successions exposed here include the Lower Triassic Kangshare Formation, the Middle Triassic Laibuxi Formation and the Upper Triassic Zhamure, Dashalong, Qulonggongba and Derirong formations (Fig. 2). These formations and the underlying Upper Permian Nimaluoshenza Formation, are briefly introduced below (terms used for describing the thickness of beds are: very-thin-, $<0.01 \mathrm{~m}$; thin-, 0.01-0.1 m; medium-, 0.1-0.5 m; and thick-bedded, 0.5-2 m).

The Upper Permian Nimaluoshenza Formation mainly comprises greyish-black shales, and is unconformably overlain by the Lower Triassic Kangshare Formation. The lower part of the Kangshare Formation is composed of yellowish-red thin-bedded limestones. Upwards, dark-green shales occur which predominate through most of the formation. The upper part of the formation is identified by grey and red limestones interbedded with greyish-green and red shales conformably overlain by sediments of the Middle Triassic Laibuxi Formation. The lithofacies within the Laibuxi Formation comprise greyblack very-thin- to thin-bedded mudstones and shales interbedded with grey fine-grained sandstones and pale-grey limestones. The Laibuxi Formation is conformably overlain by the Upper Triassic Zhamure Formation, the base of which is marked by an oncolite bed. The lithofacies comprise pale-grey limestones (weathering to yellowish-brown) interbedded with grey shales (weathering to greyish-green). The Zhamure Formation is conformably overlain by the Dashalong Formation, which is characterized by greyish-black siltstones and mudstones with grey thin- to medium-bedded limestones. The Dashalong Formation is conformably overlain by the Qulonggongba Formation, which can be subdivided into two parts: the lower part comprises greyish-green very-thin-bedded mudstones and siltstones, interbedded with greyish-black thin-bedded marlstones and grey thinbedded sandstones (weathering to pale-yellow); the upper part comprises grey thin-bedded siltstones and very-thin-bedded mudstones and grey thin- to medium-bedded sandstones (weathering to red). The Derirong Formation conformably overlies the Qulonggongba Formation, which is characterized by thin- to thick-bedded sandstones interbedded with greyish-black very-thin-bedded mudstones and siltstones. The contact between the Derirong Formation and overlying Jurassic strata is unexposed.

\section{Material and methods}

A total of 145 samples were collected for palynology: eight from the Nimaluoshenza Formation; 27 from the Kangshare Formation; eight from the Laibuxi Formation; eight from the Zhamure Formation; 17 from the Dashalong Formation; 51 from the Qulonggongba Formation; and 26 from the Derirong Formation (Fig. 3). For Middle to Upper Triassic sampling levels, see Peng et al. (2018b). Rock samples were cleaned, crushed, weighed ( $\sim 60 \mathrm{~g}$ per sample) and processed using standard hydrochloric and hydrofluoric acid palynological processing techniques (Traverse, 2007). Unoxidized residues were sieved at $200 \mu \mathrm{m}$ and $20 \mu \mathrm{m}$. All processes were performed in the palynological laboratory of Nanjing Institute of Geology and Palaeontology, Chinese Academy of Sciences (NIGPAS). Photographs were taken using an Olympus BX51 light microscope (camera DP71). All slides are housed in NIGPAS.

Counts of $\sim 200$ specimens were carried out for productive samples; in low-recovery samples, a maximum of ten slides were observed. Relative abundances of plant groups were calculated for quantitative analysis (see Supplementary Table 1 for relative abundance data). Samples with $<100$ grains of pollen and spores were excluded from vegetation and climate reconstructions. Botanical affinities of pollen and spores are summarized in Supplementary Table 2. Relative abundances and generic and species richness calculations were undertaken to investigate the vegetation and climate change. Selected pollen and spores are illustrated in Fig. 4. 


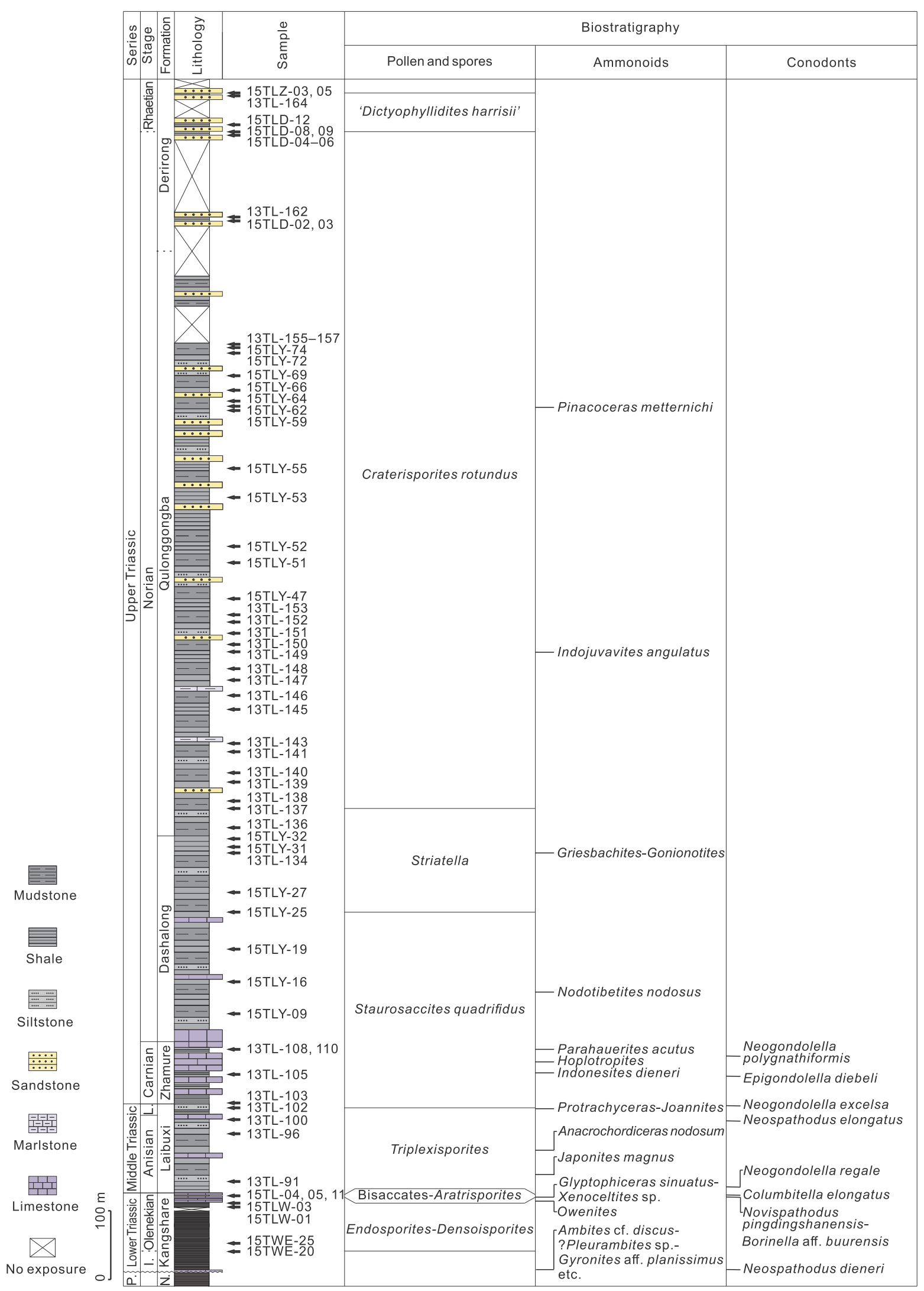

Fig. 2. Integrated biostratigraphy of the Triassic succession at Tulong (Sections A, B, C and D). Ammonoid and conodont occurrences are based on Wang and He (1976), Wang and Wang (1976) and Brühwiler et al. (2009). P. = Permian, N. = Nimaluoshenza, I. = Induan, L. = Ladinian. 


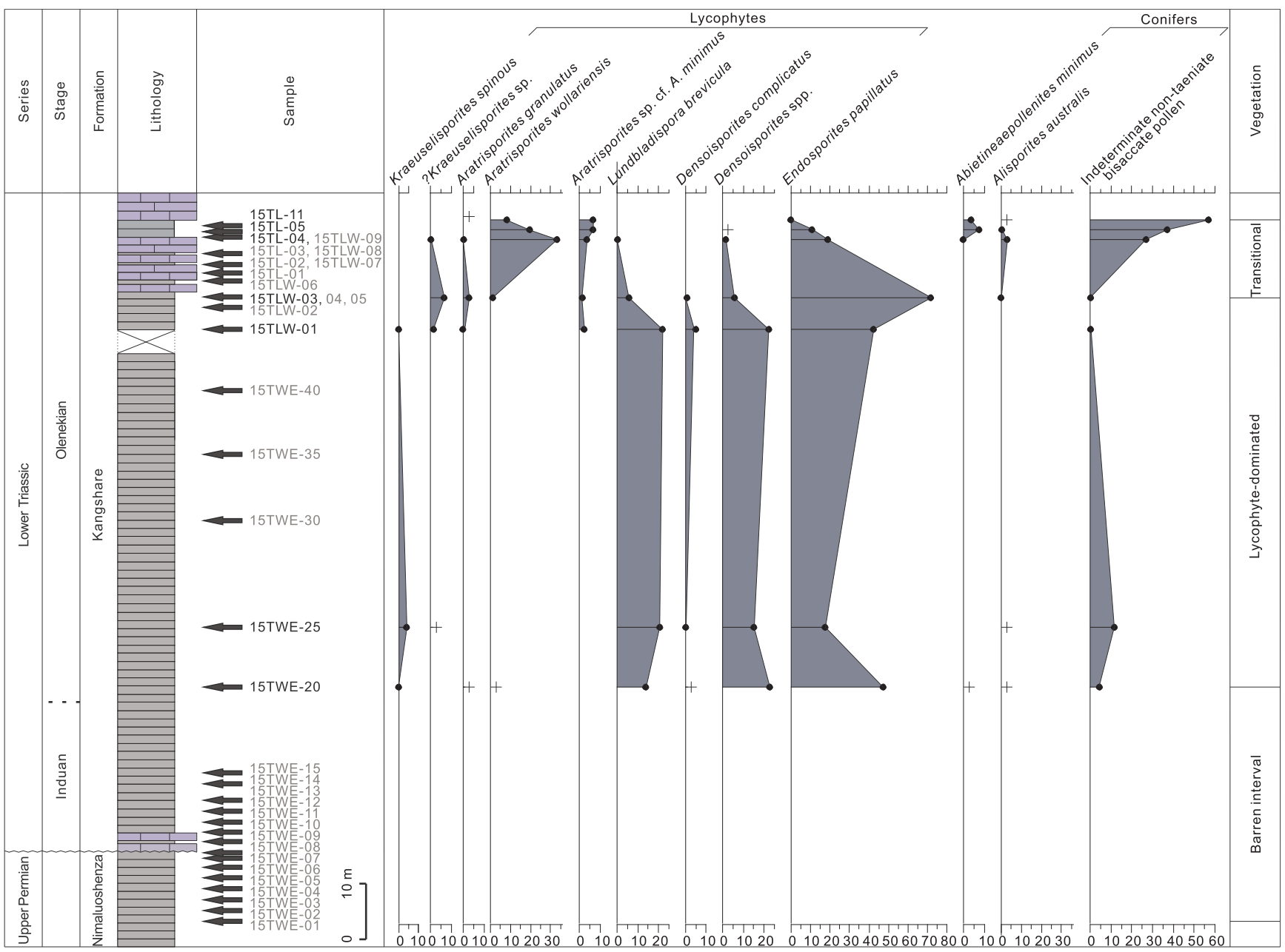

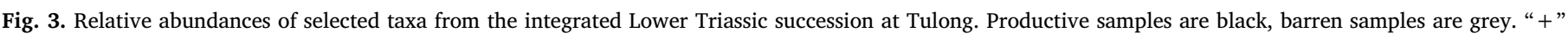
represents a relative abundance of $<3 \%$. See Fig. 2 for lithological legends.

\section{Results and discussion}

\subsection{Palynological zones}

Sixty-six out of the 145 samples were productive, hosting pollen and spores, from which seven palynological zones were recognized based on stratigraphic ranges of selected taxa and changes in their relative abundances. The uppermost Permian and lowermost Triassic strata were barren of pollen and spores, which agrees with several palaeobotanical and palynological studies from South China (Bercovici et al., 2015; Bercovici and Vajda, 2016; Cui et al., 2017). The oldest productive samples occur at $\sim 30 \mathrm{~m}$ above the Permian-Triassic unconformable contact and represent the Endosporites-Densoisporites Abundance Zone (lower Olenekian), which is overlain by the Bisaccates-Aratrisporites Abundance Zone (upper Olenekian), the Triplexisporites Interval Zone (Anisian), the Staurosaccites quadrifidus Taxon-range Zone (upper Anisian to lower Norian), the Striatella Interval Zone (lower Norian), the Craterisporites rotundus Taxon-range Zone (middle to upper Norian) and the 'Dictyophyllidites harrisii zone' (Rhaetian) (Fig. 2). The upper five zones of the Middle to Upper Triassic were described by Peng et al. (2018b); here we introduce the new miospore zones for the Lower Triassic (the Endosporites-Densoisporites Abundance Zone and the Bisaccates-Aratrisporites Abundance Zone).

\subsubsection{Endosporites-Densoisporites Abundance Zone}

Occurrence. The middle and upper parts of the shale interval of the Kangshare Formation in sections C and D (Fig. 2).
Definition. This zone is defined by high abundances of Endosporites papillatus, Densoisporites spp. and Lundbladispora spp.

Composition. The following samples are attributed to the Endosporites-Densoisporites Abundance Zone: 15TWE-20 and 15TWE-25 from section D, and 15TLW-01 and 15TLW-03 from section C. Six pollen species belonging to nine genera, and 13 spore species belonging to nine genera were identified together with indeterminable nontaeniate bisaccate pollen grains. Gymnosperm pollen comprise $1-32 \%$ of the assemblage and spores comprise $68-99 \%$. Non-taeniate bisaccate pollen are common $(8-15 \%)$, most of which are poorly preserved hampering further identification. Taeniate bisaccate pollen reach $17 \%$ in sample 15TWE-25. These include Lunatisporites pellucidus, Lunatisporites spp. and Hamiapollenites sp. Spore taxa, especially Endosporites papillatus (18-72\%), Densoisporites (8-29\%) and Lundbladispora (6-24\%), are common to abundant, and together dominate the palynoflora. Aratrisporites is rare in this zone. Spores occurring in low abundances include Annulispora spp., Calamospora mesozoica, Cyclogranisporites sp. and Punctatisporites minutus.

Age. Early Olenekian (Smithian). Ammonoids of late Induan (Dienerian) age, represented by Ambites cf. discus, ?Pleurambites sp., Gyronites aff. planissimus, Proptychites haydeni and ?Meekophiceras sp., were recorded from the limestones below the shale interval within the Kangshare Formation (Brühwiler et al., 2009) comprising the Endosporites-Densoisporites Abundance Zone (Fig. 2). The limestones also hosts the conodonts belonging to the Neospathodus dieneri group (Brühwiler et al., 2009), supporting a late Induan age. In the limestones above the shale interval that bears the Endosporites-Densoisporites 

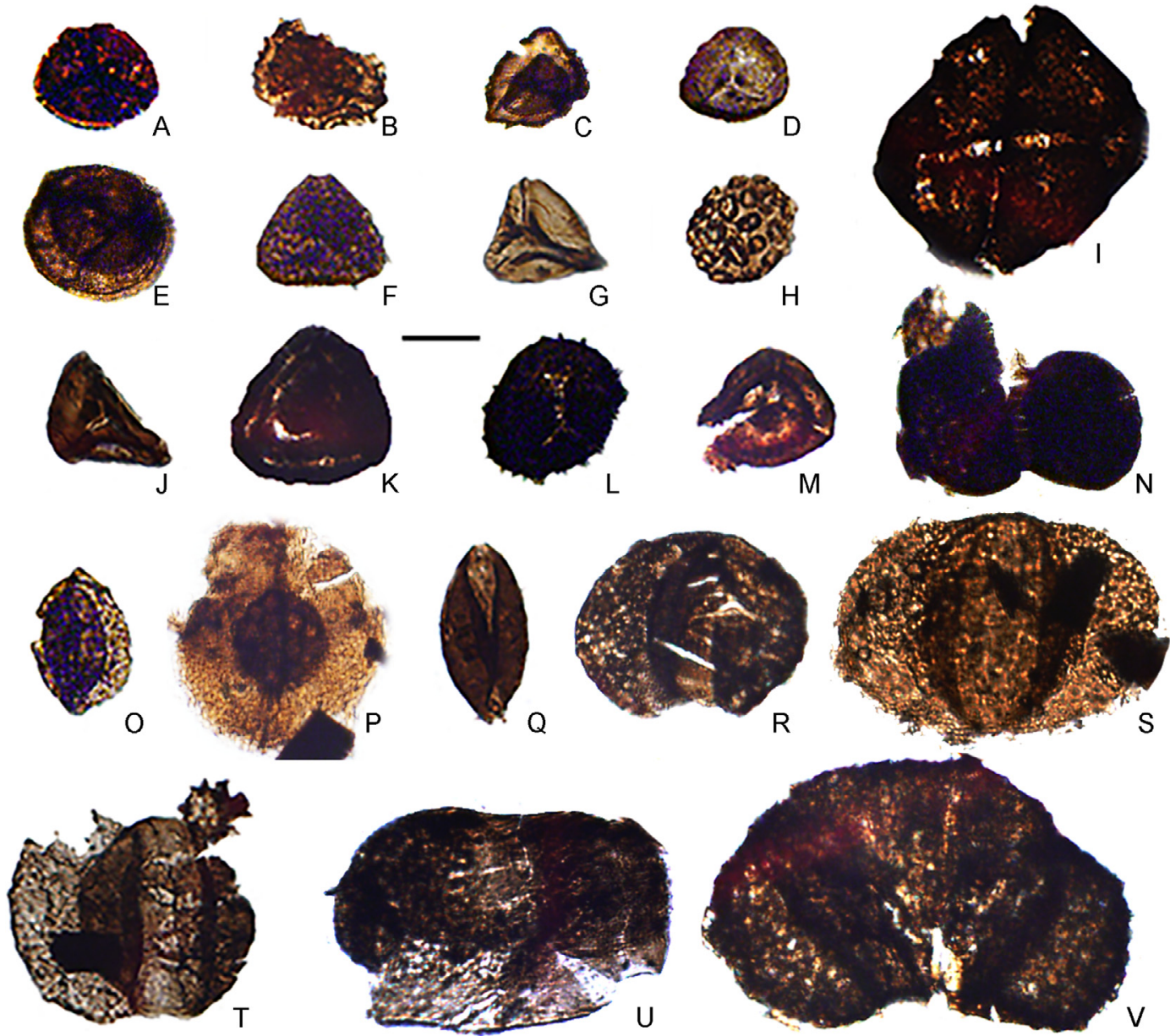



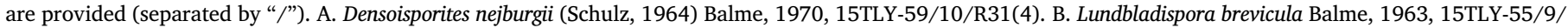

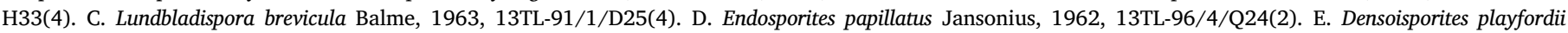

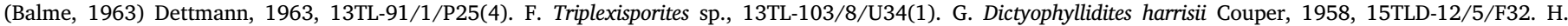

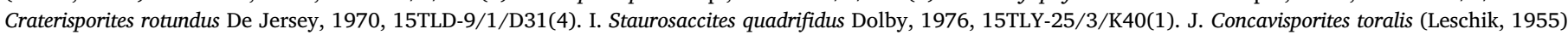

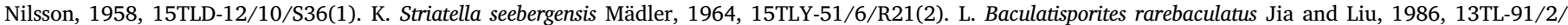

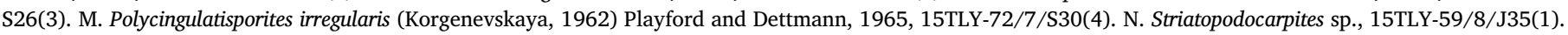

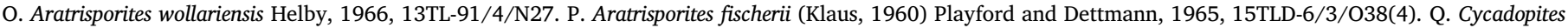



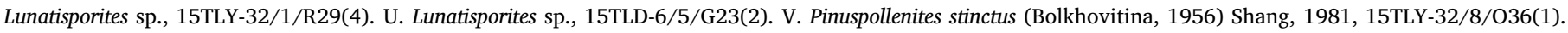
Scale bar $=20 \mu \mathrm{m}$.

Abundance Zone, the middle early Olenekian (middle Smithian) ammonoid genus Owenites was recorded (Brühwiler et al., 2009). Thus, an early Olenekian (Smithian) age is assigned to the Endosporites-Densoisporites Abundance Zone at Tulong.

Correlation. The Smithian palynoflora from the same interval described by Schneebeli-Hermann et al. (2012) compares well with the present zone in containing predominant Densoisporites and Lundbladispora, and rare Aratrisporties. Taeniate bisaccate pollen, which is relatively common in one sample (17\% in sample 15TWE-25) from the Endosporites-Densoisporites Abundance Zone, is, however, less abundant in samples described by Schneebeli-Hermann et al. (2012).

\subsubsection{Bisaccates-Aratrisporites Abundance Zone}

Occurrence. The upper part of the Kangshare Formation from section A (Fig. 2).

Definition. This zone is defined by the dominance of non-taeniate bisaccate pollen, common to abundant occurrences of Aratrisporites and Endosporites papillatus.

Composition. This zone comprises samples: 15TL-04, 15TL-05 and 15TL-11 of section A. Nine pollen species belonging to six genera, and
13 spore species belonging to 11 genera were identified together with indeterminable non-taeniate bisaccate pollen. Gymnosperm pollen comprises $34-65 \%$ of the assemblage and spores comprise $35-66 \%$. Non-taeniate bisaccate pollen dramatically increase, which reach $65 \%$ in relative abundance, including Abietineaepollenites minimus and Pinuspollenites divulgatus. Taeniate bisaccate pollen decline markedly within this zone. The spore genus Aratrisporites rises to $38 \%$ at the base but decreases to $16 \%$ at the top of this zone. Endosporites papillatus remains common (up to 19\%). The lycopod spores Densoisporites and Lundbladispora decrease dramatically in abundance compared to the preceding zone. Other rare occurrences include the spore taxa Apiculatisporis parvispinosus, A. spiniger, Baculatisporites rarebaculatus, Calamospora mesozoica, Cyathidites minor, Leiotriletes directus and Punctatisporites minutus.

Age. Late Olenekian (Spathian). Ammonoids and conodonts from the underlying and overlying limestone beds support the age constraints for this palynological zone (Fig. 2). In the underlying limestones, latest early Olenekian (latest Smithian) ammonoids Glyptophiceras sinuatus and Xenoceltites sp., and conodonts Novispathodus pingdingshanensis and Borinella aff. buurensis were recovered (Brühwiler 


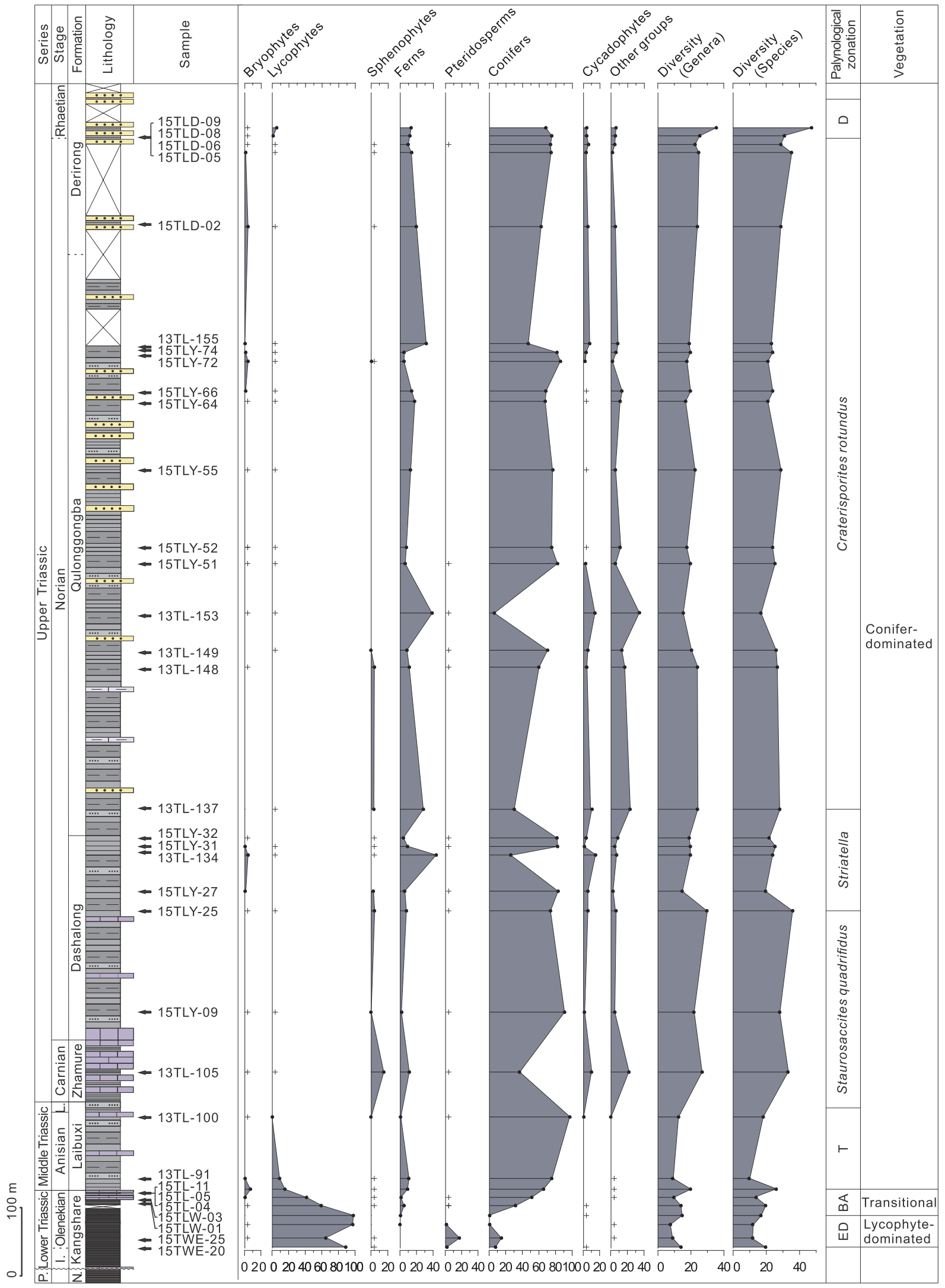

Fig. 5. Relative abundances of major vegetation components, raw richnesses of genera and species through the integrated Triassic succession at Tulong. "+" represents relative abundances of $<4 \%$. P. $=$ Permian, $\quad$ N. $=$ Nimaluoshenza, $\quad \mathrm{I} .=$ Induan, $\quad$ L. $=$ Ladinian, $\quad$ ED $=$ Endosporites - Densoisporites, $\mathrm{BA}=$ Bisaccates-Aratrisporites, $\mathrm{T}=$ Triplexisporites, $\mathrm{D}=$ Dictyophyllidites harrisii. See Fig. 2 for lithological legends. 
et al., 2009). In the overlying beds of red shales, the early late Olenekian (early Spathian) conodont Columbitella elongatus was recovered (Brühwiler et al., 2009). Thus a late Olenekian (Spathian) age assignment is interpreted for the Bisaccates-Aratrisporites Abundance Zone.

Correlation. Schneebeli-Hermann et al. (2012) described a similar Spathian palynoflora from the same part of the succession in the Tulong area, likewise this was characterized by dominant undifferentiated bisaccate pollen, abundant Aratrisporites and low abundances of Densoisporites and Lundbladispora. The slight difference between our data and those presented in Schneebeli-Hermann et al. (2012) is that taeniate bisaccate pollen slightly increased in the Spathian palynoflora of Schneebeli-Hermann et al. (2012) while we recorded a decline to rare occurrences.

\subsection{Palaeovegetation and climate}

The vegetation reconstruction (Fig. 5) was based on 33 samples; analysis of the palynological data reveals that the Triassic vegetation of Tulong comprises a mixture of bryophytes, lycophytes, sphenophytes, ferns, pteridosperms, conifers and cycadophytes. Three vegetation stages are recognized based on abundance patterns of major vegetation components: (1) lycophyte-dominated, (2) transitional and (3) coniferdominated.

The uppermost Permian in the Tulong area is represented by dark grey shales, while the basal Triassic comprises limestones interbedded with shales. Pollen and spores from the Upper Permian were previously described by Rao and Zhang (1985) from a section located to the south of Tulong Village. The assemblage contained typical Permian-Triassic elements including abundant taeniate bisaccate pollen grains and Aratrisporites (Rao and Zhang, 1985). However, in this study the Permian and basal Triassic samples were barren of pollen and spores.

The lycophyte-dominated flora at the base of the sequence occurs within the lower Olenekian Endosporites-Densoisporites Abundance Zone. This is a low-diversity assemblage overwhelmingly dominated by the lycopod spores Endosporites papillatus, Densoisporites and Lundbladispora, which together comprise $65-98 \%$ of the assemblage (Figs. 3 and 5). The dispersed lycopod spores of Densoisporites, Endosporites and Lundbladispora are morphologically comparable to spores found in situ within reproductive structures of Pleuromeia (e.g., Balme, 1995). Pleuromeia, unlike the majority of lycophytes, is thought to have occupied arid environments (e.g., Wang, 1991; Cantrill and Webb, 1998; Deng, 2007), and the proliferation of this plant is a pattern that has been recorded globally through this interval (Looy et al., 1999, 2001; Grauvogel-Stamm and Ash, 2005). Further, the absence of humid indicators also suggests an arid environment (Van Konijnenburg-Van Cittert, 2002). Pleuromeia, which records a decrease in abundance from the lower to upper Olenekian perhaps indicates a regional climate change from hot arid to more temperate humid conditions at Tulong. This is supported by oxygen isotope analyses of conodont apatite from South China and northern Pakistan (Sun et al., 2012; Romano et al., 2013), which records a positive excursion at the lower/upper Olenekian boundary corresponding to a $\sim 7.5^{\circ} \mathrm{C}$ temperature drop (Romano et al., 2013).

Pteridosperms and conifers are also present in the lycophytedominated flora, but in lower abundances. Pteridosperms are mainly represented by taeniate bisaccate pollen including Lunatisporites, Protohaploxypinus, Striatoabieites and Striatopodocarpites, which together comprise up to $17 \%$ of the lycophyte-dominated flora. Conifers are mainly represented by non-taeniate bisaccate pollen including Abietineaepollenites and Pinuspollenites, which together comprise up to $15 \%$ of the lycophyte-dominated flora. Cycadophytes are represented by Cycadopites sufflavus and occur in low abundances.

The upper Olenekian Bisaccates-Aratrisporites Abundance Zone represents a transition from the lycophyte-dominated, to the coniferdominated flora. Lycophytes, represented by Aratrisporites, Densoisporites, Endosporites papillatus and Lundbladispora, comprise 59\% of the flora in the lowermost sample of the transitional succession, but drop to $16 \%$ in the uppermost part. Among these lycophytes, Aratrisporites is dominant (16-38\%) with common Endosporites papillatus (11-19\%; Figs. 3 and 5). Fern spores, mainly represented by Apiculatisporis parvispinosus, A. spiniger, Baculatisporites rarebaculatus and Punctatisporites minutus, are present and reach up to $9 \%$ in the uppermost sample within the transitional vegetation. Conifers gradually increase in abundance through this interval and comprise $65 \%$ in the upper part of the flora (Fig. 5). Following the Olenekian, conifers remain dominant and ferns increase in abundance (Fig. 5) perhaps reflecting a shift to cooler, more temperate conditions.

The conifer-dominated flora encompasses the Middle to Upper Triassic Triplexisporites Interval Zone, the Staurosaccites quadrifidus Taxon-range Zone, the Striatella Interval Zone, the Craterisporites rotundus Taxon-range Zone and the 'Dictyophyllidites harrisii zone'. Conifers, represented by the pollen Abietineaepollenites, Pinuspollenites and indeterminate non-taeniate bisaccate pollen, remain abundant and comprise $98 \%$ of the palynological assemblage in sample 13TL-100, suggesting an expansion of conifer forests during the Anisian. Cycadophytes, represented by Cycadopites spp., Chasmatosporites elegans and Monosulcites sp., increase in abundance in the Carnian and represent up to $15 \%$ of the conifer-dominated flora. Spores of sphenophytes comprise up to $15 \%$ in the lower Carnian, which subsequently decrease in abundance following the upper Carnian. Ferns are slightly more abundant and exhibit higher raw richnesses in the conifer-dominated flora compared to the transitional flora (21 species in 14 genera compared to five species in four genera). Lycophytes, pteridosperms and bryophytes are rare in the conifer-dominated flora (Fig. 5).

\subsection{Regional tectonic evolution and vegetation changes}

During the Early Triassic, the Tulong area of southern Xizang was situated on the northern margin of Gondwana (Ogg and von Rad, 1994). The breakup of Gondwana at this time, through the rifting of the Lhasa Block from the southern Xizang Block, initiated the opening of Neo-Tethys (e.g., McLoughlin, 2001; Pan et al., 2012; Metcalfe, 2013).

The Triassic succession in the Tulong area exhibits a shift from an epicontinental sea basin to a deep water rift basin (Shi, 2001; Brühwiler et al., 2009). This process started with an extensional stage during the latest Permian to Early Triassic when the Tulong area subsided slowly to form an epicontinental sea basin. A deepening upwards trend is apparent according to the low energy water in the uppermost part of the lower Olenekian (Brühwiler et al., 2009). The increased input of siliciclastics in the upper Olenekian shales and the development of red limestones immediately above, suggests a deepening of the marine environment. The facies of the red limestones resembles the wellknown 'Ammonitico Rosso' facies from the Jurassic of the Mediterranean region, which has been interpreted as a deep outer shelf plateau setting (Brühwiler et al., 2009). Increased oceanic currents would have likely entered the basin with more water vapor, increasing precipitation in the Tulong area. Following the late Olenekian, humidity gradually increased, providing an improved environment for the ferns. Since the Anisian, the epicontinental basin further extended and deepened to form a deep water rift basin in the Late Triassic (Shi, 2001). At this time, the basin entered a tectonically stable stage, in parallel with the evolution of a stable conifer-dominated flora and a humid and temperate climate (Fig. 6).

Twelve sequences have been identified in the Tulong succession based on sequence stratigraphy, which include four sea level highs (sequences TSq1-4) in the Lower Triassic (Shi, 2001) (Fig. 6). The sequence TSq2 has been correlated with the global Triassic sea level high in the early Olenekian (Haq, in press) (Fig. 6). The early Olenekian transgression in the Tulong area was the largest of the Early Triassic (Shi, 2001), but the largest Early Triassic transgression in the global record occurred during the Induan (Haq, in press; Fig. 6), suggesting that the regional sea levels in the early Olenekian were strongly 


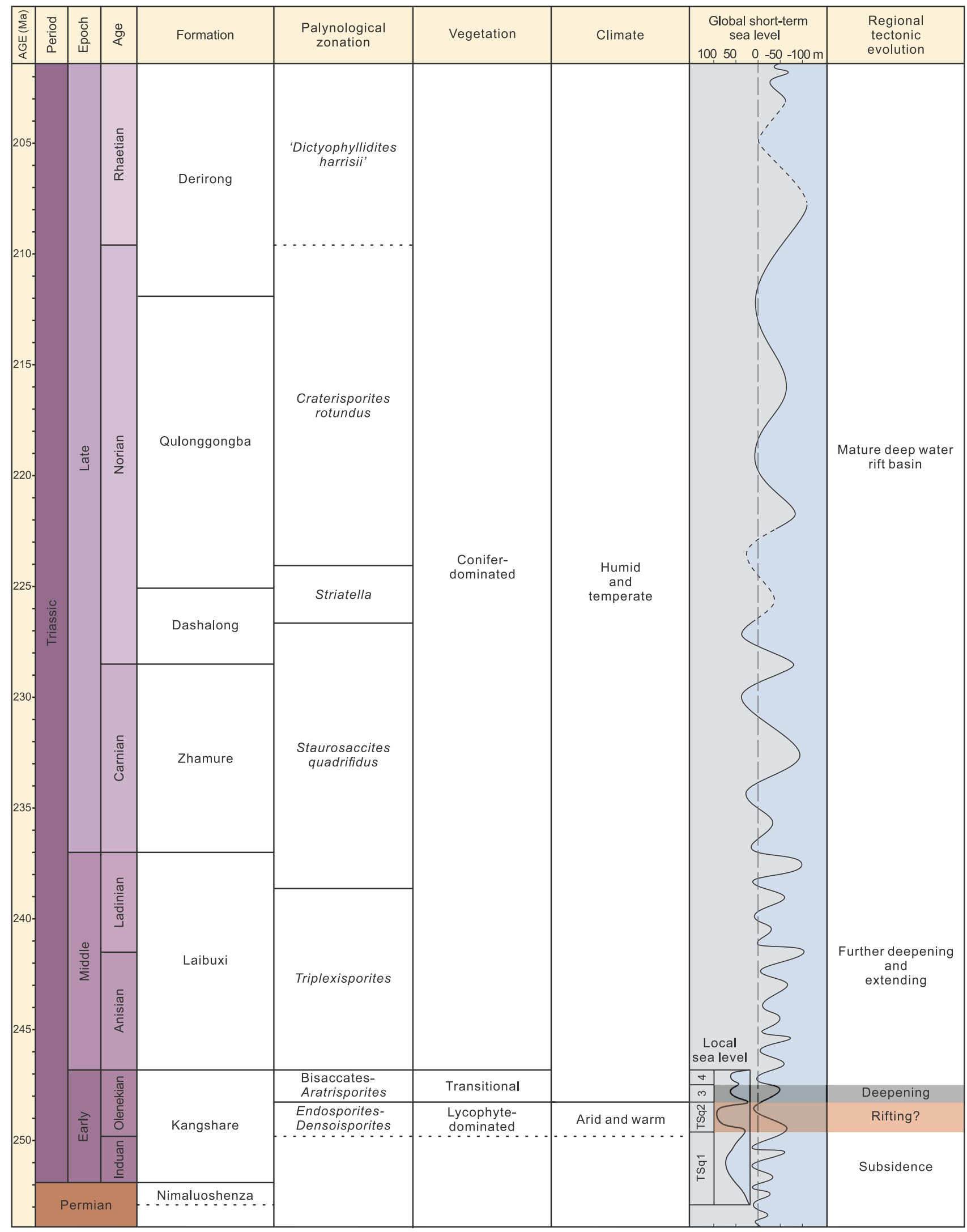

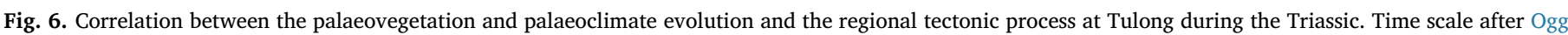

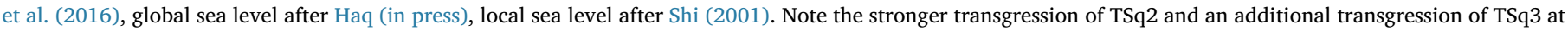
Tulong compared to the global sea-level changes, which is probably a result of regional rifting and deepening (highlighted by shaded blocks). 
influenced/controlled by regional tectonics. In the Tulong area, the early late Olenekian transgression following TSq2 contrasts the global regression (Fig. 6), which is likely a result of enhanced regional tectonic movements or specifically, the ongoing rifting of northern Gondwana.

\section{Conclusions}

Three floras were recognized through the Triassic succession of the Tulong area, southern Xizang (Tibet): (1) an early Olenekian lycophytedominated flora; (2) a late Olenekian transitional flora; and (3) a Middle to Late Triassic mature conifer-dominated flora. Based on changes in dispersed pollen and spore assemblages we record significant shifts in dominant parent-plant abundances that suggest a regional cooling and increase in humidity during the Olenekian. The rifting of northern Gondwana is hypothesized as a driving factor for shifts in vegetation communities in the Tulong area.

\section{Acknowledgements}

We thank Ms Feng Limei and Zhang Xuansi (NIGPAS) for technical help in processing the samples. We thank the reviewers and editors for their constructive comments on this manuscript. This work was supported by the Strategic Priority Research Program (B) of the Chinese Academy of Sciences (grant numbers XDB26010206, XDB18000000, XDB03010103), the National Natural Science Foundation of China (grant number 41688103), Key Laboratory of Economic Stratigraphy and Palaeogeography, Chinese Academy of Sciences (grant number 2017KF07), UNESCO grant IGCP 632, the Swedish Research Council (grant number 2015-4264) and the Wenner-Gren Foundation (grant number UPD2017-0155).

\section{Appendix A. Supplementary material}

Supplementary data associated with this article can be found, in the online version, at https://doi.org/10.1016/j.jseaes.2018.06.005.

\section{References}

Balme, B.E., 1995. Fossil in situ spores and pollen grains: an annotated catalogue. Rev. Palaeobotany Palynol. 87, 81-323.

Bercovici, A., Cui, Y., Forel, M.-B., Yu, J.X., Vajda, V., 2015. Terrestrial paleoenvironment characterization across the Permian-Triassic boundary in South China. J. Asian Earth Sci. 98, 225-246.

Bercovici, A., Vajda, V., 2016. Terrestrial Permian-Triassic boundary sections in South China. Global Planet. Change 143, 31-33.

Cui, Y., Bercovici, A., Yu, J.X., Kump, L.R., Freeman, K.H., Su, S.G., Vajda, V., 2017. Carbon cycle perturbation expressed in terrestrial Permian-Triassic boundary sections in South China. Global Planet. Change 148, 272-285.

Brühwiler, T., Goudemand, N., Galfetti, T., Bucher, H., Baud, A., Ware, D., Hermann, E., Hochuli, P.A., Martini, R., 2009. The Lower Triassic sedimentary and carbon isotope records from Tulong (South Tibet) and their significance for Tethyan palaeoceanography. Sedimentary Geol. 222, 314-332.

Cantrill, D.J., Webb, J.A., 1998. Permineralized pleuromeid lycopsid remains from the Early Triassic Arcadia Formation, Queensland, Australia. Rev. Palaeobotany Palynol. $102,189-211$.

Deng, S.H., 2007. Palaeoclimatic implications of main fossil plants of the Mesozoic. J. Palaeogeogr. 9, 559-574.

Deng, S.H., Lu, Y.Z., Fan, R., Pan, Y.H., Cheng, X.S., Fu, G.B., Wang, Q.F., Pan, H.Z., Shen, Y.B., Wang, Y.Q., Duan, W.Z., Zhang, H.C., Jia, C.K., Fang, L.H., 2010. The Jurassic System of Northern Xinjiang, China. University of Science and Technology of China Press, Hefei, pp. 1-279.

Grauvogel-Stamm, L., Ash, S.R., 2005. Recovery of the Triassic land flora from the endPermian life crisis. C. R. Palevol. 4, 593-608.

Haq, B.U., in press. Triassic ocean and sea levels reexamined. https://www.researchgate. net/project/Revision-of-the-Triassic-Sea-Level-curve/update/ 5a8be6ff4cde266d588c5226.

Huang, Z.G., Zhou, H.Q., 1980. Palaeobotany. In: Institute of Geology, Chinese Academy of Geological Sciences (Ed.), Mesozoic Stratigraphy and Palaeontology of the Shaanxi-Gansu-Ningxia Basin. Geological Publishing House, Beijing, pp. 43-114.

Kustatscher, E., Ash, S.R., Karasev, E., Pott, C., Vajda, V., Yu, J.X., McLoughlin, S., 2018. Flora of the Late Triassic. In: Tanner, L.H. (Ed.), Late Triassic of the World. Topics in Geobiology 46. Springer, Cham, pp. 545-622.

Li, L.Q., Wang, Y.D., 2016a. Late Triassic palynofloras in the Sichuan Basin, South China: synthesis and perspective. Palaeoworld 25, 212-238.

Li, L.Q., Wang, Y.D., Liu, Z.S., Zhou, N., Wang, Y., 2016b. Late Triassic palaeoclimate and palaeoecosystem variations inferred by palynological record in the northeastern Sichuan Basin, China. Paläontologische Zeitschrift 90, 327-348.

Li, L.Q., Wang, Y.D., Vajda, V., Liu, Z.S., 2017. Late Triassic ecosystem variations inferred by palynological records from Hechuan, southern Sichuan Basin, China. Geol. Mag. http://dx.doi.org/10.1017/S0016756817000735.

Looy, C.V., Brugman, W.A., Dilcher, D.L., Visscher, H., 1999. The delayed resurgence of equatorial forests after the Permian-Triassic ecologic crisis. Proc. Natl. Acad. Sci. USA 96, 13857-13862.

Looy, C.V., Twitchett, R.J., Dilcher, D.L., Van Konijnenburg-Van Cittert, J.H.A., Visscher, H., 2001. Life in the end-Permian dead zone. Proc. Natl. Acad. Sci. USA 98, $7879-7883$.

McLoughlin, S., 2001. The breakup history of Gondwana and its impact on pre-Cenozoic floristic provincialism. Austral. J. Botany 49, 271-300.

Metcalfe, I., 2013. Gondwana dispersion and Asian accretion: tectonic and palaeogeographic evolution of eastern Tethys. J. Asian Earth Sci. 66, 1-33.

Ogg, J.G., von Rad, U., 1994. The Triassic of the Thakkhola (Nepal). II: Paleolatitudes and comparison with other eastern Tethyan margins of Gondwana. Geologische Rundschau 83, 107-129.

Ogg, J.G., Ogg, G.M., Gradstein, F.M., 2016. A Concise Geologic Time Scale. Elsevier, Amsterdam, pp. 1-234.

Pan, G.T., Wang, L.Q., Li, R.S., Yuan, S.H., Ji, W.H., Yin, F.G., Zhang, W.P., Wang, B.D., 2012. Tectonic evolution of the Qinghai-Tibet Plateau. J. Asian Earth Sci. 53, 3-14.

Peng, J.G., Li, J.G., Li, W.B., Slater, S.M., Zhu, H.C., Vajda, V., 2018a. The Triassic to Early Jurassic palynological record of the Tarim Basin, China. Palaeobiodivers. Palaeoenviron. 98, 7-28.

Peng, J.G., Li, J.G., Slater, S.M., Li, W.B., Zhu, H.C., Vajda, V., 2018b. Triassic palynostratigraphy and palynofloral provinces: evidence from southern Xizang (Tibet), China. Alcheringa 42, 67-86.

Qu, L.F., 1980. Triassic spores and pollen. In: Institute of Geology, Chinese Academy of Geological Sciences (Ed.), Mesozoic Stratigraphy and Palaeontology of the ShaanxiGansu-Ningxia Basin. Geological Publishing House, Beijing, pp. 115-143.

Rao, R.B., Zhang, Z.G., 1985. A discovery of Permo-Triassic transitional fauna in the Qomolangma Feng area: its implications for the Permo-Triassic boundary. Xizang (Tibet) Geology 1, 19-31.

Rao, R.B., Xu, J.F., Chen, Y.M., Zou, D.B., 1987. The Triassic System of the QinghaiXizang Plateau. Geological Publishing House, Beijing, pp. 1-239.

Romano, C., Goundemand, N., Vennemann, T.W., Ware, D., Schneebeli-Hermann, E., Hochuli, P.A., Brühwiler, T., Brinkmann, W., Bucher, H., 2013. Climatic and biotic upheavals following the end-Permian mass extinction. Nat. Geosci. 6, 57-60.

Schneebeli-Hermann, E., Hochuli, P.A., Bucher, H., Goudemand, N., Brühwiler, T. Galfetti, T., 2012. Palynology of the Lower Triassic succession of Tulong, South Tibet-evidence for early recovery of gymnosperms. Palaeogeogr., Palaeoclimatol., Palaeoecol. 339-341, 12-24.

Sha, J.G., Vajda, V., Pan, Y.H., Larsson, L., Yao, X.G., Zhang, X.L., Wang, Y.Q., Cheng, X.S., Jiang, B.Y., Deng, S.H., Chen, S.W., Peng, B., 2011. Stratigraphy of the TriassicJurassic boundary successions of the southern margin of the Junggar Basin, northwestern China. Acta Geologica Sinica 85, 421-436.

Sha, J.G., Olsen, P.E., Pan, Y.H., Xu, D.Y., Wang, Y.Q., Zhang, X.L., Yao, X.G., Vajda, V., 2015. Triassic-Jurassic climate in continental high-latitude Asia was dominated by obliquity-paced variations (Junggar Basin, Ürümqi, China). Proc. Natl. Acad. Sci. USA 112, 3624-3629.

Shi, X.Y., 2001. Triassic sequence stratigraphy and sedimentary evolution in the Qomolongma area, southern Xizang (Tibet)—from epicontinental sea to basin. Acta Geol. Sin. 75, 292-302

Sun, Y.D., Joachimski, M.M., Wignall, P.B., Yan, C.B., Chen, Y.L., Jiang, H.S., Wang, L.N., Lai, X.L., 2012. Lethally hot temperatures during the Early Triassic greenhouse. Science 338, 366-370.

Traverse, A., 2007. Paleopalynology, second edition. Springer, Dordrecht, pp. 1-813.

Van Konijnenburg-Van Cittert, J.H.A., 2002. Ecology of some Late Triassic to Early Cretaceous ferns in Eurasia. Rev. Palaeobotany Palynol. 119, 113-124.

Wang, C.Y., Wang, Z.H., 1976. Triassic conodonts from the Mt Qomolangma area. In: Tibet Expedition Team of Academia Sinica, A Report of Scientific Expedition to the Mt. Qomolangma Area 1966-1968 (Palaeontology 2). Science Press, Beijing, pp. 387-424.

Wang, Y.D., Fu, B.H., Xie, X.P., Huang, Q.S., Li, K., Li, G., Liu, Z.S., Yu, J.X., Pan, Y.H., Tian, N., Jiang, Z.K., 2010. The Terrestrial Triassic and Jurassic Systems in the Sichuan Basin, China. University of Science and Technology of China Press, Hefei, pp. $1-216$.

Wang, Y.G., He, G.X., 1976. Triassic ammonoids from the Mt Qomolangma area. In: Tibet Expedition Team of Academia Sinica, A Report of Scientific Expedition to the Mt. Qomolangma Area 1966-1968 (Palaeontology 3). Science Press, Beijing, pp. 223-502.

Wang, Y.G., Sun, D.L., He, G.X., 1980. New advances in the stratigraphy of the Himalayas (China's side). J. Stratigraphy 4, 55-59.

Wang, Z.Q., 1991. Advances on the Permo-Triassic lycopods in North China I. An Isoetes from the mid-Triassic in northern Shaanxi Province. Palaeontographica B 222, 1-30.

Yin, A., Harrison, T.M., 2000. Geologic evolution of the Himalayan-Tibetan Orogen. Annu. Rev. Earth Planet. Sci. 28, 211-280.

Zhang, Y.C., Shi, G.R., Shen, S.Z., 2013. A review of Permian stratigraphy, palaeobiogeography and palaeogeography of the Qinghai-Tibet Plateau. Gondwana Res. 24 $55-76$. 